\title{
Multiplex Immunoassay and Bead Based Multiplex
}

\author{
Türkan Yiğitbaşı \\ Izmir Katip Çelebi University \\ Turkey
}

\section{Introduction}

\subsection{Background}

Protein immunoassays provide information about quantities and forms of endogenous proteins. Uniplex enzyme immunoassays like Elisa have been the workhorse for protein measurement for decades, but they can be laborious and expensive and consume relatively large amounts of specimen. In comparison to the ELISA for a single analyte, multiplex assays offer the possibility of obtaining more reliable quantitative information in a highly parallel analysis. In addition, quantitative multiplexed assays offer the possibility to identify combinations of biomarkers with higher disease specificity than any single established biomarker alone. Because of these reasons, currently one-analysis, many-metabolites, manydiseases approach is receiving more attention than uniplex system with one-analysis, onemetabolite, one-disease.

\subsection{Multiplex immunoassay platforms}

Presently, antibody-based platforms are the core technology for protein multiplex arrays. Assay formats include suspension arrays (microbead assays) and planar arrays that use traditional immunometric principles.

Planar arrays: MULTI-ARRAY (Meso Scale Discovery), A2 (Beckman Coulter), and FAST Quant (Whatman Schleicher \& Schuell BioScience), Searchlight (Aushon Biosystem).

Suspension arrays: Bio-Plex (Bio-Rad Laboratories), FlowCytomix (Bender MedSystems), cytometric bead array (Becton, Dickinson and Company) and the partners of Luminex Corp (XMAP)].

In the first format, different capture antibodies are spotted at defined positions on a 2dimensional array. In the second, the capture antibodies are conjugated to different populations of microbeads, which can be distinguished by their fluorescence intensity in a flow cytometer.

Optimal assay performance of multiplex immunoassay platforms depend on proprietary information about the antibody pair, the composition of diluents, and the software. The accuracy of quantification for multiplexed immunoassays depends, as with all ELISAs, on the quality of the calibration curves, assay imprecision $(\mathrm{CV})$, recoveries, and assay linearity 
(the limits of quantification). Therefore, there is not a single assay platform suitable for all analytes. The selection of a platform or kit should depend on assay sensitivity, the relevant biological concentration to be measured

\begin{tabular}{|l|l|l|l|}
\hline Platform & $\begin{array}{l}\text { MesoScale discovery } \\
\text { (MULTI- } \\
\text { ARRAY/MULTI-SPOT) }\end{array}$ & Searchlight & $\begin{array}{l}\text { FastQuant } \\
\text { (FAST Quant System) }\end{array}$ \\
\hline $\begin{array}{l}\text { Capture antibody } \\
\text { binding surface }\end{array}$ & Carbon & Plastic & Nitrocellulose \\
\hline Detection system & Electrochemiluminescent & $\begin{array}{l}\text { Biotinylated } \\
\text { detector with } \\
\text { fluorescent } \\
\text { detection }\end{array}$ & $\begin{array}{l}\text { Biotinylated detector } \\
\text { with fluorescent } \\
\text { detection }\end{array}$ \\
\hline Analytes/plex & Up to 10 & Up to 24 & Up to 10 \\
\hline Image System & CCD camera based & $\begin{array}{l}\text { CCD camera } \\
\text { based }\end{array}$ & CCD camera based \\
\hline Customised array & Yes & Yes & Yes \\
\hline $\begin{array}{l}\text { Kits for designing } \\
\text { and building } \\
\text { your own assay }\end{array}$ & Yes & No & No \\
\hline Reagent company & $\begin{array}{l}\text { Waterman Scleicher\& } \\
\text { Schuell Bioscience }\end{array}$ & $\begin{array}{l}\text { Aushon } \\
\text { Biosystem }\end{array}$ & $\begin{array}{l}\text { Waterman Scleicher\& } \\
\text { Schuell Bioscience }\end{array}$ \\
\hline $\begin{array}{l}\text { Commercial } \\
\text { instrument }\end{array}$ & $\begin{array}{l}\text { Waterman Scleicher\& } \\
\text { Schuell Bioscience }\end{array}$ & $\begin{array}{l}\text { Aushon } \\
\text { Biosystem }\end{array}$ & $\begin{array}{l}\text { Waterman Scleicher\& } \\
\text { Schuell Bioscience }\end{array}$ \\
\hline
\end{tabular}

Table 1. The characteristics of some commercial planar microspot array platforms

\begin{tabular}{|l|l|l|}
\hline Platform & Luminex & Cytometric Bead Array (CBA) \\
\hline $\begin{array}{l}\text { Capture antibody } \\
\text { binding surface }\end{array}$ & Fluorescently tagged beads & Fluorescently labeled beads \\
\hline Detection system & $\begin{array}{l}\text { Biotinylated detector with } \\
\text { fluorescent detection }\end{array}$ & $\begin{array}{l}\text { Phycoerythrin conjugated } \\
\text { detectors }\end{array}$ \\
\hline Analytes/plex & Up to 100 & Up to 100 \\
\hline Image System & Luminex XMAP based system & Flow cytometer with dual laser \\
\hline Customised array & Yes & Yes \\
\hline $\begin{array}{l}\text { Kits for designing } \\
\text { and building your } \\
\text { own assay }\end{array}$ & Yes & Yes \\
\hline $\begin{array}{l}\text { Reagent company } \\
\text { partners(many others) }\end{array}$ & Lumine(XMAP) and its partners & BD Becton,Dickinson and others \\
\hline $\begin{array}{l}\text { Commercial } \\
\text { instrument }\end{array}$ & BD Becton,Dickinson and others \\
\hline
\end{tabular}

Table 2. The characteristics of some commercial suspension bead array platforms 


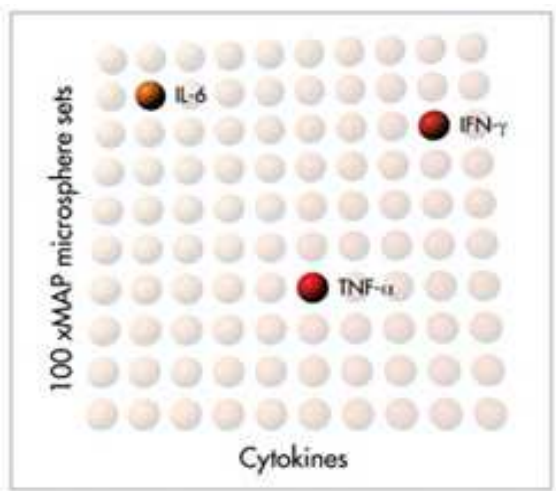

1. Microspheres are dyed to create 100 distinct colors

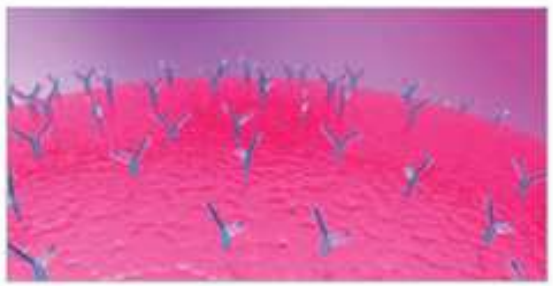

2. Microspheres are coated with capture antibody

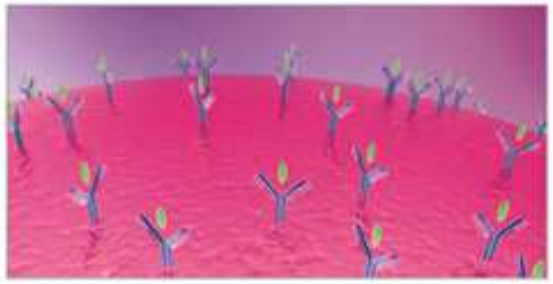

3. Sample is added to microspheres and analyte is captured

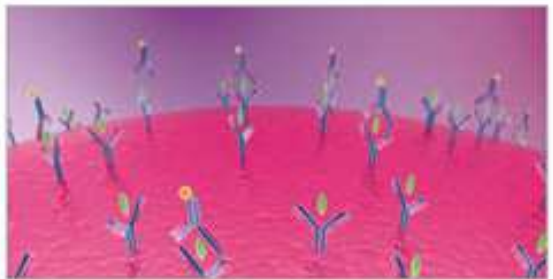

\section{Fluorescent tagged detection antibody is added}

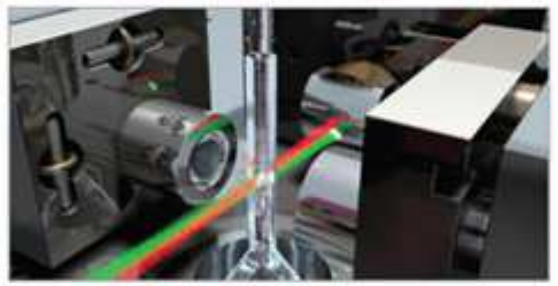

\section{Lasers detect both} bead dyes and tagged detection antibody

Fig. 1. Process of multiplexed immunodetection using fluorescent-coded beads (www.millipore.com) 


\section{Bead based multiplex}

\subsection{Background}

In multiplex bead array assays (MBAA), beads of discrete fluorescence intensities and wavelengths provide a capture surface for specific analytes enabling detection of multiple analytes in a single sample. Bead based assays of analyte is an attractive strategy for obtaining large numbers of measurements rapidly. MBAA is an open access system; namely, the parameters to be measured can be determined by the user. The variety of source increases its area of application (nucleic acids, antigens, antibodies, receptors).Since the detection method is based on flow cytometry and this allows repeatability, MBAA performs the quality control of the measurement, simultaneously with the measurement itself.

The MBAA readers allow analysis of up to 100 reactions or assays per well. This remarkable capability allows incorporating a large number of assays, such as DNA, receptor-ligand, Immunoassay and enzyme in life science research, drug discovery as well as diagnostic areas.

\subsection{The principle of measurement}

These systems depend on measurement of fractional antibody occupancy using two different labels: one labeling the "capture" antibody, the second labeling a "detection antibody", selected to react either with occupied or unoccupied sites on the "capture" antibody. The ratio of signals emitted by the two labeled antibodies reveals the analyte concentration to which the capture antibody has been exposed. An array of capture antibodies, each labeled with the same fluorescent label, is scanned (by a laser), and the fluorescent signal ratio emitted from each discrete antibody couplet in the array is measured.

\subsection{Summary of principles}

1. Color-coded beads, pre-coated with analyte-specific capture antibody for the molecule of interest are added.

2. Analyte-specific antibodies capture the analyte of interest. Biotinylated detection antibodies specific to the analyte of interest are added and form an antibody-antigen sandwich.

3. Phycoerythrin (PE)-conjugated Streptavidin is added.

4. The beads are read by a dual-laser flow-based detection instrument which excites the internal dyes marking the beads set and a second laser excites PE, the fluorescent dye on the reporter molecule (www.luminexcorp.com).

The system is capable of measuring potentially up to 100 analytes simultaneously in a small sample volume $(25-50 \mu \mathrm{L})$.

\subsection{Advantages of the system}

1. Speed/High Throughput - Because each microsphere serves as an individual test, a large number of different assays can be performed and analyzed simultaneously

2. Versatility - Bead based multiplex system can perform assays in several different formats, including nucleic acids and antigen-antibody binding, along with enzyme, receptor-ligand and other protein interactions 
3. Flexibility - The technology can be customized for the user's specific needs based upon their analytes of interest

4. Accuracy - The technology generates real-time analysis and accurate quantification of the biological interactions (www.luminexcorp.com).

Advantages of this approach also include specimen conservation, limited sample handling, and decreased time and cost. However, it is difficult to optimize assay format for each protein, to select common dilution factors and to establish reliable quality control algorithms.

\begin{tabular}{|c|c|}
\hline Characteristics & Antibody-based \\
\hline Principle & Antibody-antigen interaction \\
\hline Required reagents/information & Specific antibody pairs \\
\hline Quantification basis & flowcytometer and others \\
\hline Multiplexicity & Yes \\
\hline Clinical diagnostic test & No \\
\hline Sample enrichment & >sub ng/mL-pg/mL \\
\hline Sensitivity & Time and resource demanding \\
\hline Reproducibility & High demand \\
\hline Assay development & Yes \\
\hline Consumable & High \\
\hline Robustness & Yes \\
\hline Throughput & No \\
\hline Matrix effect & Yes \\
\hline Sample manipulation & $>15$ years \\
\hline Automation &
\end{tabular}

Table 3.The characteristics of MBAA

\subsection{Comparison with other technologies and assays}

The assay which is most often compared to MBAA is the enzyme-linked immunosorbent assay (ELISA). ELISAs, in general, use a similar immobilized antibody to capture a soluble ligand, with subsequent detection of the captured ligand by a second antibody. There are, however, several substantial differences between MBAA and ELISAs. For example, MBAA uses fluorescence as a detection system where ELISAs use enzyme amplification of a colorimetric substrate. MBAA captures ligands onto spherical beads in suspension while ELISAs generally rely upon flat surfaces in 96-well plates. Most importantly, MBAA techniques, by their very nature, are multiplexed and therefore may be subject to any perturbations that arise from analyzing multiple ligands simultaneously, such as crossreactivities. By contrast, ELISA methodologies generally study one analyte at a time, and thus avoid any concerns arising from multiplexing.

Multiplex system presents additional Quality control (QC) challenges compared to uniplex analyses. The failure of 1 constituent assay to meet QC specifications results in rejection of results for all assays on the panel. Samples failing QC specifications should be retested using the same measurement system, because substitution of a uniplex assay may introduce bias 
due to differences in assay format. However, the probability of all assays simultaneously meeting QC specifications is much lower than the probability of a uniplex test passing QC. At present, reference guidelines for multiplex QC programs are under development by the Food and Drug Administration (FDA).

In theory, the MBAA platform may also provide a wider dynamic range than conventional ELISA methods because of the greater linear range of fluorescence intensity compared with absorbance. Detection limits of MBAA (luminex) and ELISA are different. A comparison of detection limits of some test for the Luminex assays and the ELISAs is shown in Table 4. Data Supplement (available at http://www.clinchem.org/content/vol51/issue7/) Disadvantage of MBAA are time consuming in assay development, lacking antibody pairs for new biomarkers and limited commercial multiplex assay kits.

\begin{tabular}{|l|l|l|l|l|}
\hline Multiplex panels & Analytes & Luminex & ELISA & $\begin{array}{l}\text { ELISA } \\
\text { manufacturer }\end{array}$ \\
\hline Linco Endocrine & Leptin & $0.13 \mu \mathrm{g} / \mathrm{L}$ & $1.39 \mu \mathrm{g} / \mathrm{L}$ & Linco \\
\hline & Insulin & $0.31 \mathrm{mIU} / \mathrm{L}$ & $0.14 \mathrm{mIU} / \mathrm{L}$ & Alpco \\
\hline & C-peptide & $0.037 \mu \mathrm{g} / \mathrm{L}$ & $0.132 \mu \mathrm{g} / \mathrm{L}$ & Linco \\
\hline Biosource Chemokine & MCP-1 & $2.35 \mathrm{ng} / \mathrm{L}$ & $2.57 \mathrm{ng} / \mathrm{L}$ & R\&D \\
\hline & Eotaxin & $4.37 \mathrm{ng} / \mathrm{L}$ & $3.80 \mathrm{ng} / \mathrm{L}$ & R\&D \\
\hline Upstate Chemokine & MCP-1 & $20.5 \mathrm{ng} / \mathrm{L}$ & $2.57 \mathrm{ng} / \mathrm{L}$ & R\&D \\
\hline & Eotaxin & $27.72 \mathrm{Eotaxin}$ & $3.80 \mathrm{ng} / \mathrm{L}$ & R\&D \\
\hline Linco Cytokine & TNF-a & $1.61 \mathrm{ng} / \mathrm{L}$ & $0.092 \mathrm{ng} / \mathrm{L}$ & R\&D \\
\hline & IL-8 & $2.52 \mathrm{ng} / \mathrm{L}$ & $0.26 \mathrm{ng} / \mathrm{L}$ & Biosource \\
\hline Upstate Cytokine & TNF-a & $0.065 \mathrm{ng} / \mathrm{L}$ & $0.092 \mathrm{ng} / \mathrm{L}$ & R\&D \\
\hline & IL-8 & $0.70 \mathrm{ng} / \mathrm{L}$ & $0.26 \mathrm{ng} / \mathrm{L}$ & Biosource \\
\hline & IL-6 & $0.75 \mathrm{ng} / \mathrm{L}$ & $0.068 \mathrm{ng} / \mathrm{L}$ & R\&D \\
\hline R\&D Cytokine & TNF-a & $1.53 \mathrm{ng} / \mathrm{L}$ & $0.092 \mathrm{ng} / \mathrm{L}$ & R\&D \\
\hline & IL-6 & $0.977 \mathrm{ng} / \mathrm{L}$ & $0.068 \mathrm{ng} / \mathrm{L}$ & R\&D \\
\hline
\end{tabular}

Table 4. Comparison of detection limits for the Luminex multiplexed assays and the individual ELISAs.

Protein microarray kits, which use capture antibodies and detection antibodies in a multiplex fashion similar to MBAA, should also be considered as a competing technology which is most commonly used for simultaneous determination of multiple proteins in a biological fluid. The technique uses primary antibodies as the immobilized probe on a solid surface, and protein antigens labeled with fluorophores with or without bound secondary antibodies are recognized and detected. However, binding of antibodies and antigens to a solid support can cause denaturation or drying of proteins. MBAA provides multiplexing in a solution phase and thus is particularly flexible and nondestructive for protein analysis. Also protein microarray assay are relatively new, are not widely accepted as a 'gold standard' for clinical use, and also may be of limited sensitivity.

\subsection{Areas of application}

Since a disease can result from various reasons and it may include functional disorders of multiple genes, a multi analyte analysis is necessary for diagnostic purposes. The 
technology called omic and multiplex system allows a fast and systematic detection of the effects of micro molecules in different molecular and cellular contexts. In this respect, it can be used for diagnosing multi-reason/multi-gene diseases, performing a comprehensive disease management and investigating complex cellular functions. In addition, it provides a wide range of application area for research area because of its plasticity which allows the researchers to perform various studies.

\subsection{Clinical utility}

Despite the introduction of hundreds of multiplexed protein immunoassays to the research market in recent years, only a limited number have been cleared by the FDA for clinical use, an observation that illustrates the complexity of constructing robust arrays. Antibody-based multiplexed assay (and commercial instruments and kits) have a relatively long history with over 15 years of development and optimization. However, most commercial multiplex assays are developed for research laboratories and nonclinical tests; only a limited number of multiplex assays are approved by FDA for clinical testing. For example FDA-cleared planar protein multiplex arrays consist primarily of the lateral flow immunoassays used for point-ofcare evaluation . For example, the Triage ${ }^{\circledR}$ Cardio ProfilER ${ }^{\circledR}$ 4-plex measures troponin-I, creatine kinase-MB, myoglobin, and brain natriuretic peptide (BNP) to assist with evaluation of chest pain using a portable lateral flow platform. At present, suspension immunoassay is the prevailing technology for FDA-cleared multiplex protein measurements, especially for testing antibodies in the serum of patients with allergies or autoimmune or infectious diseases in clinical laboratories.

The other platforms for commercial multiplex diagnostic tests include Luminex (www.luminex.com), Triage system (www.Biosite.com), Evidence (www.Randox.com), Vidas (www.biomerieux-diagnostics. com), Planner arrays (www.VBC-genomics), Whatman (www.whatman.com) and bead array (www.bioarrays.com). At present, suspension immunoassay is the prevailing technology for FDA-cleared multiplex protein measurements, especially for testing antibodies in the serum of patients with allergies or autoimmune or infectious diseases in clinical laboratories. Most of the currently available multiplex immunoassays have been designed to quantify the concentrations of various cytokines.The recent development of spectrally-distinguishable fluorescent beads(Luminex) (Kellar and Iannone, 2002) has resulted in the widespread use of antigen-coupled beads for monitoring antibodies in sera by flow cytometry. These bead arrays have been adapted for serologic screening of antigens and have been described for up to ten antigens for HIV (Opalka et al., 2004), HPV (Opalka et al., 2003; Dias et al., 2005), Epstein-Barr virus (Klutts et al., 2004; Binnicker et al., 2008; Gu et al., 2008), B. anthracis (Biagini et al., 2004; Biagini et al., 2005), Influenza (Drummond et al., 2008) and M.tuberculosis (Khan et al.,2008).

The results from a growing number of research studies, demonstrate that multiplex technology may be useful in clinical research to measure a large number of analytes to examine the association with a clinical phenotype and the effects of therapeutic interventions, and that this technology may be particularly useful when sample volume is limited, such as in large epidemiologic studies and clinical trials. Clinical applications must follow establishment of globally accepted calibration standards, performance criteria, and QC programs. 


\begin{tabular}{|c|c|c|}
\hline APPLICATION & AVAILABLE KITS* & COMPANY \\
\hline Allergy Testing & $\begin{array}{l}\text { Alternaria (Mold) (h), Bermuda Grass (h), Cat Dander (h), Egg } \\
\text { White (h), Milk (h), Mite Pternoyssinus (h), Mountain Cedar (h), } \\
\text { Short Ragweed (h), Timothy Grass (h), Wheat (food) (h) }\end{array}$ & $\operatorname{ImTech}(\mathrm{h})$ \\
\hline Autoimmune & $\begin{array}{l}\text { ASCA (h), beta-2 Microglobulin (h,m), Centromere B (h), } \\
\text { Chromatin (h), DNA (h),ENA Profile } 4 \text { (SSA, SSB, Sm, ENA Profile } \\
\text { 5 SSA, SSB, Sm, RNP, Scl-70) (h), ENA Profile } 6 \text { (SSA, SSB, Sm, } \\
\text { RNP, Scl-70, Jo-1) (h), Gliadin A (h), Gliadin G (h), Histone (h), } \\
\text { Histone H1 (h), Histone H2A (h), Histone H2B (h), Histone H3 (h), } \\
\text { Histone H4 (h), HSP-27 pS82 (G), HSP-27 Total (G), HSP-32 (h), } \\
\text { HSP-65 (h), HSP-71 (h), HSP-90 a (h), HSP-90 b (h), Jo-1 (h), PCNA } \\
\text { (h,m), PR3 (h), PR3 (cANCA) (m), RF (h), Ribosomal P (h,m), RNP } \\
\text { (h,m), RNP-A (h), RNP-C (h), SCF (h,m), Scl-70 (h,m), Serum } \\
\text { Amyloid P (h), SLE Profile 8 (SSA, SSB, Sm, RNP, Scl-70, Jo-1, } \\
\text { Ribosome-P, chromatin) (h), Sm (G) (h), Smith (h,m), SSA (h,m), } \\
\text { SSB (h,m), Streptolysin O (h), TG (h), } \\
\text { TPO (h,m), Transglutaminase A (h), Transglutaminase G (h) }\end{array}$ & RBM(h,m) \\
\hline Cancer Markers & $\begin{array}{l}\text { Alpha Fetoprotein (h), Cancer Antigen } 125 \text { (h), Carcinoembryonic } \\
\text { Antigen (h), PSA, Free (h) }\end{array}$ & RBM(h) \\
\hline Cardiac Markers & $\begin{array}{l}\text { Creatine Kinase-MB (h), Endothelin-1 (m), PAP }(\mathrm{h}), \text { SGOT }(\mathrm{h}, \mathrm{m}), \\
\text { TIMP-1 }(\mathrm{h}, \mathrm{m})\end{array}$ & RBM(h,m) \\
\hline Cytokine & $\begin{array}{l}\text { Abeta } 40 \text { (h), Abeta } 42 \text { (h), BDNF (h), DR-5 (h), EGF (h,m), ENA-78 } \\
\text { (h), Eotaxin (h,m), Fatty Acid Binding Protein (h), FGF-basic (h,m), } \\
\text { G-CSF (h,m), GCP-2 (m), GM-CSF (h,m,rt), GRO alpha (h), GRO- } \\
\text { KC (rt), HGF (h,m), I-TAC (h), ICAM-1 (h), IFN-alpha (h), IFN- } \\
\text { gamma (h,m,rt), IL-10 (h,m,rt), IL-11 (m), IL-12 (h,m), IL-12 p40 } \\
(\text { h,m), IL-12 p40/ p70 (m) (rt), IL-12 p70 (h,m,rt), IL-13 (h,m), IL-15 } \\
(\text { h,m), IL-16 (h), IL-17 (h,m), IL-18 (rt), IL-1alpha (h,m,rt), IL-1beta } \\
(\mathrm{h}, \mathrm{m}, \mathrm{rt}), \mathrm{IL}-1 \mathrm{ra}(\mathrm{h}), \mathrm{IL}-1 \mathrm{ra} / \mathrm{IL}-1 \mathrm{~F} 3(\mathrm{~h}), \mathrm{IL}-2 \text { (h,m,rt), IL-3 (h,m), IL-4 } \\
(\mathrm{h}, \mathrm{m}, \mathrm{rt}), \mathrm{IL}-5 \text { (h,m,rt), IL-6 (h,m,rt), IL-7 (h,m), IL-8 (h), IL-9 (m), IP- } \\
\text { 10 (h,m), JE/MCP-1 (m), KC (m), KC/GROa (m), LIF (m), IL-8 (h), } \\
\text { IL-9 (m), IP-10 (h,m), JE/MCP-1 (m), KC (m), KC/GROa (m), LIF } \\
\text { (m), MCP-3(h,m), MCP-5 (m) }\end{array}$ & $\begin{array}{l}\text { B-R(m); } \\
\text { Bios (h,m,rt); } \\
\text { Linco (h,m,rt); } \\
\text { RD(h,m); } \\
\text { UP(h,m), RBM } \\
(\mathrm{h}, \mathrm{m})\end{array}$ \\
\hline $\begin{array}{l}\text { EndocrineACTH } \\
\text { (h), Adiponectin } \\
(\mathrm{h}, \mathrm{m}), \text { Amylin } \\
(\mathrm{m})(\mathrm{rt})(\mathrm{h}), \mathrm{C}- \\
\text { Peptide (h), } \\
\text { Calcitonin (h), } \\
\text { CRF Linco }\end{array}$ & $\begin{array}{l}\text { ACTH (h), Adiponectin (h,m), Amylin (m) (rt) (h), C-Peptide (h), } \\
\text { Calcitonin (h), CRF(h), FGF-9 (m), FSH (h), GH (h), GLP-1 (h,m,rt), } \\
\text { Glucagon (m) (rt) (h), Growth Hormone (h,m), Insulin (h,m,rt), } \\
\text { Leptin (h,m,rt), LH (h), Lipoprotein (a) (h), PAI-1(active) (h), PAI-1 } \\
\text { (total) (h,m), Prolactin (h), Resistin (h,m,rt), T3 (h), T4 (h), TBG (h), } \\
\text { Thyroglobulin (h), TSH (h) }\end{array}$ & $\begin{array}{l}\text { Linco }(h, \mathrm{~m}, \mathrm{rt}) \\
\operatorname{RBM}(\mathrm{h}, \mathrm{m})\end{array}$ \\
\hline Gene Expression & $\begin{array}{l}\text { IL6R(h), ACTB (h), BAD (h), BAK1 (BAK) (h), BCL2 (h), BCL2L1 } \\
\text { (BCL-XL) (h), CDKN1A (CDKN1) (h), CFLAR (CFLIP) (h), CSF2 } \\
\text { (h), GAPD (h), IFN-gamma (h), IL-1 beta (h), IL-10 (h), IL-2 (h), IL-6 } \\
\text { (h), IL-8 (h), NFKB2 (h), NFKBIA (NFKIA) (h), NKFB1 (h), PPIB } \\
\text { (h), Ptk2B (RAFTK) (h), RELA (h), RELB (h), TNF (h), TNFAIP3 } \\
\text { (A20) (h), TNFRSF6 (FAS) (h), TNFSF6 (FASL) (h), VEGF (h) }\end{array}$ & $\begin{array}{l}\text { Bios (h); } \\
\text { MBio (h) }\end{array}$ \\
\hline MMP & $\begin{array}{l}\text { MMP-1 (h), MMP-12 (h), MMP-13 (h), MMP-2 (h), MMP-3 (h), } \\
\text { MMP-7 (h), MMP-8(h), MMP-9 (h) }\end{array}$ & RD (h); Bios (h) \\
\hline Genotyping & $\begin{array}{l}\text { FlexMAPTM }(G) \text {, Mitochondrial DNA Screening (h), Tag-It } \\
\text { Mutation Detection Kit }(G) \text {, Y-SNP Identification }(\mathrm{h})\end{array}$ & $\begin{array}{l}\text { Bio (h), Mira(h), } \\
\text { TmBio }(\mathrm{h})\end{array}$ \\
\hline
\end{tabular}




\begin{tabular}{|c|c|c|}
\hline APPLICATION & AVAILABLE KITS* & COMPANY \\
\hline $\begin{array}{l}\text { Infectious } \\
\text { Disease }\end{array}$ & $\begin{array}{l}\text { Adenovirus (h,m), Bordetella pertussis (h), Campylobacter jejuni } \\
\text { (h), Chlamydia pneumoniae (h), Chlamydia trachomatis (h), } \\
\text { Cholera Toxin (h), Cholera Toxin b (h), Clostridium piliforme } \\
\text { (Tyzzer's) (m), Cytomegalovirus (h,m), Diphtheria Toxin (h), } \\
\text { Ectromelia virus (m), EDIM (Epidemic diarrhea of infant mice) (m), } \\
\text { Encephalitozoon cuniculi (m), Epstein-Barr EA (h), Epstein-Barr } \\
\text { NA (h), Epstein-Barr VCA (h), HBV Core (h), HBV Envelope (h), } \\
\text { HBV Surface (Ad) (h), HBV Surface (Ay) (h), HCV Core (h), HCV } \\
\text { NS3 (h), HCV NS4 (h), HCV NS5 (h), Helicobacter pylori (h), } \\
\text { Hepatitis A (h), Hepatitis D (h), HEV orf2 3KD (h), HEV orf2 6KD } \\
\text { (h), HEV orf3 3KD (h), HIV-1 gp120 (h), HIV-1 gp41 (h), HIV-1 p24 } \\
\text { (h), HPV (h), HSV-1 gD (h), HSV-1/2 (h), HSV-2 gG (h), HTLV-1/2 } \\
\text { (h), Influenza A (h), Influenza A H3N2 (h), Influenza B (h), } \\
\text { Leishmania donovani (h), Lyme disease (h), Lymphocytic } \\
\text { choriomeningitis virus (m), M. pneumoniae (h), M. tuberculosis (h), } \\
\text { Minute virus (m), Mumps (h), Mycoplasma pulmonis (m), } \\
\text { Parainfluenza 1 (h), Parainfluenza } 2 \text { (h), Parainfluenza } 3 \text { (h), } \\
\text { Parvovirus (m), Pneumonia virus of mice (m) }\end{array}$ & RBM (h,m) \\
\hline Isotyping & $\begin{array}{l}\operatorname{IgA}(\mathrm{h}, \mathrm{m}), \operatorname{IgE}(\mathrm{h}, \mathrm{m}), \operatorname{IgG} 1(\mathrm{~m}), \operatorname{IgG} 2 \mathrm{alpha}(\mathrm{m}), \operatorname{IgG} 2 \text { beta }(\mathrm{m}), \operatorname{IgG} 3 \\
(\mathrm{~m}), \operatorname{IgM}(\mathrm{h}, \mathrm{m}), \text { light chain (kappa or gamma) (m) }\end{array}$ & $\begin{array}{l}\mathrm{UP}(\mathrm{h}, \mathrm{m}) \\
\mathrm{RBM}(\mathrm{h}, \mathrm{m})\end{array}$ \\
\hline $\begin{array}{l}\text { Metabolic } \\
\text { Markers }\end{array}$ & $\begin{array}{l}\text { Apolipoprotein A-1 (m), Apolipoprotein A-I (h), Apolipoprotein } \\
\text { A-II (h), Apolipoprotein B (h), Apolipoprotein C-II (h), } \\
\text { Apolipoprotein C-III (h), Apolipoprotein E (h), beta-2 Glycoprotein } \\
\text { (h,m), Collagen Type } 1 \text { (h), Collagen Type 2(h), Collagen Type } 4 \text { (h), } \\
\text { Collagen Type } 6 \text { (h), Glutathione S-Transferase (h,m), } \\
\text { Pancreatic Islet Cells (h), tTG (Celiac Disease) (h) }\end{array}$ & $\begin{array}{l}\text { RBM }(h, m) \\
\text { Linco }\end{array}$ \\
\hline Tissue Typing & $\begin{array}{l}\text { HLA Class I and II (h), HLA Class I Single Antigen Antibody, } \\
\text { Group } 1 \text { (h), HLA Class I Single Antigen Antibody, Group } 2 \text { (h), } \\
\text { PRA Class I (h), PRA Class I and II (h), PRA Class II (h), SSO Class I } \\
\text { HLA-A (h), SSO Class I HLA-B (h), SSO Class I HLA-C(h), SSO } \\
\text { Class II DP (h), SSO Class II DQB1 (h), SSO Class II DRB1 (h), SSO } \\
\text { Class II DRB3,4,5 (h) }\end{array}$ & Lambda (h) \\
\hline $\begin{array}{l}\text { Kinase } \\
\text { Phosphorylated } \\
\text { Protein }\end{array}$ & $\begin{array}{l}\text { Akt (G), Akt (Ser473) (G), Akt (total) (G), Akt/PKB (total) (G), } \\
\text { Akt/PKBpS473 (G), ATF2 (Thr71) (G), ATF2 (total) (G), CREB } \\
\text { (pS133) (G), CREB (Total) (G), Erk 1/2(pTpY185/187) (G), Erk 1/2 } \\
\text { (Total) (G), Erk-2 (G), Erk1 (Thr202/Tyr204) (G), Erk1/2 } \\
\text { (Thr202/Tyr204, Thr185/Tyr187) (G), Erk2 (Thr185/Tyr187) (G), } \\
\text { Erk2 (total) (G),GSK 3beta (pS9) (G), GSK-3a/b (Ser21/Ser9) (G), } \\
\text { GSK-3beta (G), IGF 1R }\end{array}$ & $\operatorname{UP}(\mathrm{G}), \operatorname{Bios}(\mathrm{G})$ \\
\hline $\begin{array}{l}\text { Transcription } \\
\text { Factors-Nuclear } \\
\text { Receptors }\end{array}$ & $\begin{array}{l}\text { AP-2 (G), CREB (G), EGR (h), HIF-1 (h), NF-1 (h), NFAT (h), NFkB } \\
\text { Gene Family(h), PPAR (h), SRE (h), YY1 (h) }\end{array}$ & $\begin{array}{l}\text { Bios (h), MBio } \\
\text { (h) }\end{array}$ \\
\hline
\end{tabular}

${ }^{*}$ Human (h), mouse (m): rat (rt): general (G), ImmuneTech (ImTech); Rules Based Medicine (RBM); BioRad (B-R); BioSource (Bios); Linco Research (Linco); Qiagen; R\&D Systems (RD); and Upstate Group (UP); Marligen Biosciences (MBio), MiraBio (Mira); Tm BioScience (TmBio); One Lambda (LAMBDA).

Table 5. Aplication area and available kits 


\section{References}

[1] Multiplexed Analysis of Biomarkers Related to Obesity and the Metabolic Syndrome in Human Plasma, Using the Luminex-100 System. Liu M.Y, Xydakis A.M, Hoogeveen R.C, Jones P.H, O’Brian Smith E, Nelson K.W, Ballantyn C.M. Clinical Chemistry.2005;51(7):1102-1109 .

[2] Multiplex assays for biomarker research and clinical application: Translational science coming of age. Fu Q, Schoenhoff F.S, Savage W.J, Zhang P, Van Eyk J.E.Proteomics Clin. Appl. 2010;4:271-284.

[3] Comparison of multiplex immunoassay platforms. Fu Q, Zhu J, Van Eyk JE. Clin Chem. 2010;56(2):314-8.

[4] Measurement and Quality Control Issues in Multiplex Protein Assays: A Case Study. Ellington A.A, Kullo I.J, Bailey K.R, Klee G.G. Clin Chem. 2009; 55(6): 1092-1099.

[5] Multi-analyte immunoassay. Ekins RP.Journal of Pharmaceutical and Biomedical Analysis.1989; 7(2):155-168.

[6] US Food and Drug Administration. Guidance for industry and FDA staff: pharmacogenetic tests and genetic tests for heritable markers. (Accessed October 2011].

[7] Multiplexed protein measurement: technologies and applications of protein and antibody arrays. Kingsmore S.F. Nat Rev Drug Discov. 2006; 5(4): 310-3208.

[8] Antibody-Based Protein Multiplex Platforms: Technical and Operational Challenges. Ellington A.A, Kullo IJ, Bailey K.R, Klee G.G. Clin Chem. 2010; 56(2): 186-193.

[10] Rapıd Detectıon of Antıbodıes In Sera Using Multıplexed Self-Assembling Bead Arrays. Wonga J, Sibanib S, Lokkoa N.N, LaBaerb J, Andersona K. J Immunol Methods. 2009; 31: 171-182.

[11] Multiplex Bead Array Assays: Performance Evaluation and Comparison of Sensitivity to ELISA. Elshal M.F, McCoy J.P. Methods. 2006; 38(4): 317-323.

[12] Obez Hastalarda Büyüme Hormonu, Leptin, Amilin,Glukagon Benzeri Peptid-1 Seviyeleri ile İnsülin Direnci Arasındaki İlişki [Relationship Between The Levels of Growth Hormone, Leptin, Amylin,Glucagon Like Peptide-1 and Insulin Resistance in Obese Patients]. Yiğitbaşı T,Baskın Y, Afacan G, Harmanda A. Turkish Journal of Biochemistry 2010; 35 (3); 177-182.

[13] Eotaxin and Interleukin-4 Levels and Their Relation to Sperm Parameters in Infertile Men. Yiğitbası T,Baskın Y, Afacan G, Karaarslan F, Taheri C, Aslan D. Turkiye Klinikleri J Med Sci 2010;30 (5)1441-1445. 


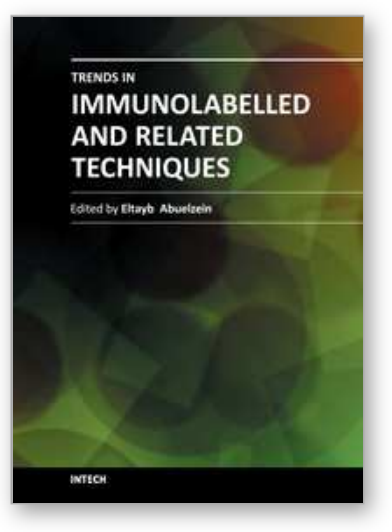

\author{
Trends in Immunolabelled and Related Techniques \\ Edited by Dr. Eltayb Abuelzein
}

ISBN 978-953-51-0570-1

Hard cover, 360 pages

Publisher InTech

Published online 27, April, 2012

Published in print edition April, 2012

The book is coined to provide a professional insight into the different trends of immunoassay and related techniques. It encompasses 22 chapters which are grouped into two sections. The first section consists of articles dealing with emerging uni-and-multiplex immunolabelled methods employed in the various areas of research. The second section includes review articles which introduce the researchers to some immunolabelled techniques which are of vital significance such as the use of the conjugates of the Staphylococcus aureus protein "A" and the Streptococcus Spps. protein "G" in immunolabelled assay systems, the use of bead-based assays and an overview on the laboratory assay systems. The book provides technological innovations that are expected to provide an efficient channel for developments in immunolabelled and related techniques. It is also most useful for researchers and post-graduate students, in all fields, where immunolabelled techniques are applicable.

\title{
How to reference
}

In order to correctly reference this scholarly work, feel free to copy and paste the following:

Türkan Yiğitbaşı (2012). Multiplex Immunoassay and Bead Based Multiplex, Trends in Immunolabelled and Related Techniques, Dr. Eltayb Abuelzein (Ed.), ISBN: 978-953-51-0570-1, InTech, Available from: http://www.intechopen.com/books/trends-in-immunolabelled-and-related-techniques/bead-based-multiplex

\section{INTECH}

open science | open minds

\author{
InTech Europe \\ University Campus STeP Ri \\ Slavka Krautzeka 83/A \\ 51000 Rijeka, Croatia \\ Phone: +385 (51) 770447 \\ Fax: +385 (51) 686166 \\ www.intechopen.com
}

\author{
InTech China \\ Unit 405, Office Block, Hotel Equatorial Shanghai \\ No.65, Yan An Road (West), Shanghai, 200040, China \\ 中国上海市延安西路65号上海国际贵都大饭店办公楼 405 单元 \\ Phone: +86-21-62489820 \\ Fax: +86-21-62489821
}


(C) 2012 The Author(s). Licensee IntechOpen. This is an open access article distributed under the terms of the Creative Commons Attribution 3.0 License, which permits unrestricted use, distribution, and reproduction in any medium, provided the original work is properly cited. 